\title{
THE CHRONOLOGY AND STATUS OF NON NOK THA, NORTHEAST THAILAND
}

\author{
C.F.W. Higham ${ }^{1}$, T.F.G. Higham ${ }^{2}$ and K. Douka ${ }^{2}$ \\ ${ }^{1}$ Department of Anthropology and Archaeology, University of Otago, charles.higham@otago.ac.nz \\ ${ }^{2}$ Research Laboratory for Archaeology and the History of Art, University of Oxford, thomas.higham@rlaha.ox.ac.uk and kateri- \\ na.douka@rlaha.ox.ac.uk
}

\begin{abstract}
Non Nok Tha was discovered 50 years ago, and has long been established as one of the key sites of Southeast Asian prehistory. Excavations by Bayard and Solheim in 1966 and 1968 uncovered what is still one of the largest assemblages of prehistoric burials in this region. It documents settlement by early Neolithic rice farmers, and incorporates the transition into the Bronze Age. Initial publications claimed exceptionally early copper base technology, and both the chronology and the social correlates of early agriculture and metallurgy have attracted much attention, and remain controversial. This paper presents a new series of AMS radiocarbon determinations obtained on collagen derived from the bones of those who lived at Non Nok Tha. These indicate an initial settlement phase by rice farmers that began in the mid second millennium BC. The Bronze Age cemetery dates between about 900-600 BC. The relatively few mortuary offerings in both phases suggest minimal social ranking.
\end{abstract}

\section{INTRODUCTION}

Non Nok Tha is a small and low mound located adjacent to the eastern flank of the Phu Wiang escarpment on the Khorat Plateau, NE Thailand (102 $18^{\prime} 17^{\prime \prime} \mathrm{E}, 16^{\circ} 47^{\prime} 57^{\prime \prime}$ $\mathrm{N}$, Figure 1). Pioneering excavations at the site by Bayard and Parker began in 1966 and were undertaken over two seasons.

Many difficulties were encountered (Parker 2010). In the absence of a roof to cover the squares, soils hardened rapidly in the sun, and dried to a monochrome grey. The locally available tools were not suited to delicate excavation in a site little over a metre deep, and incorporating, according to the published sections, up to 21 layers. It was necessary to work with local villager excavators in a foreign language. Above all, the cultural sequence comprised a maze of intercutting graves, postholes, pits and other disturbances. The soils were too hard to undertake screening, meaning that smaller material, such as fish bones and beads, were not identified. A further intractable problem was the rarity of in situ charcoal in sufficient quantities for conventional radiocarbon dating, which was then the norm.

This paper is concerned with the Neolithic and Bronze Age contexts, with particular reference to the 11 mortuary phases identified in two areas at the site. Early Periods
(EP) 1-3 are interpreted as belonging to the Neolithic, although a socketed bronze axe was found in a late EP3 grave. Thereafter, the four Middle Period (MP) phases of the 1968 area are associated with the Bronze Age, and are known as MP1, 4, 5 and 6. MP2, 3, 7 and 8 were found in the area opened in 1966.

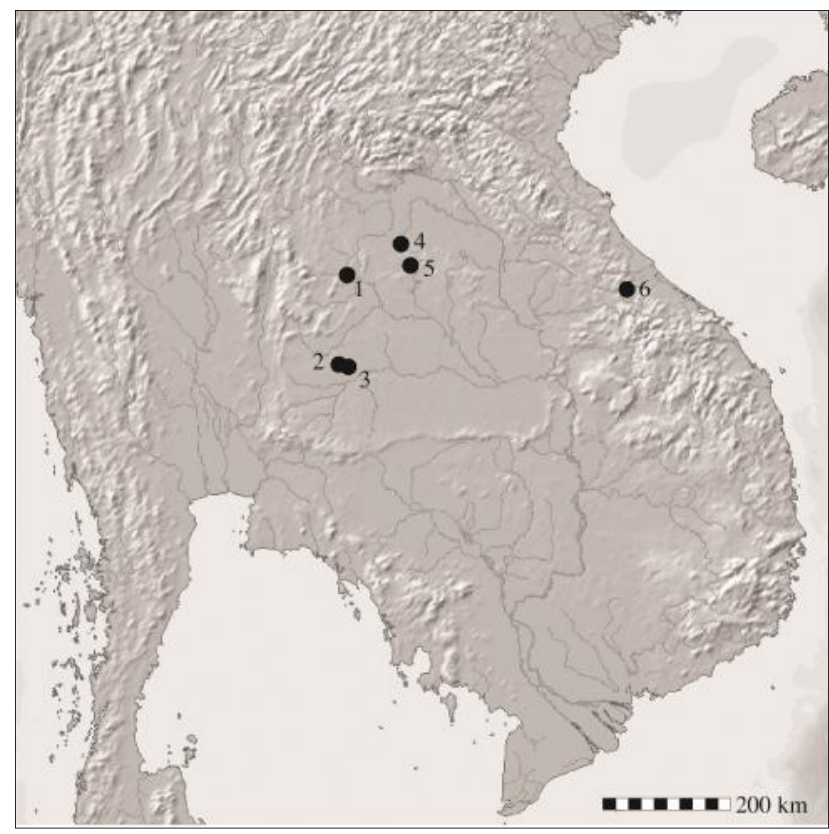

Figure 1: The location of the sites mentioned in the text. 1. Non Nok Tha, 2. Ban Non Wat, 3. Ban Lum Khao, 4. Ban Chiang, 5. Ban Na Di, 6. Sepon.

Bayard (2010a) has provided a detailed description of the provenance of each radiocarbon sample, with comments on their reliability for dating. Four materials were dated: charcoal, bone, the organic fraction of ceramic tempers and ceramics by thermoluminescence. As is well documented, no coherent sequence has been obtained (Spriggs 1996-7). Charcoal is now avoided where possible, due to the often unknown degree of inbuilt age from dating old wood. The organic fraction of ceramic tempers is also suspect, because clay itself can contain old carbon and thus provide a spuriously early result (Bonsall et al. 2002, Berstan et al. 2008). In the case of Non Nok Tha, Bayard also stressed that the sherds dated were not from mortuary pots and their provenance was in doubt. Bone 
collagen has only become a reliable source for dating since improvements have been made to purification methods. There are five TL dates on ceramics. EP1 burial 14 is dated to $2995 \pm 320 \mathrm{BC}$, burial 90 of $\mathrm{EP} 3$ to $2420 \pm 200 \mathrm{BC}$, burial 73 to $2420 \pm 200$ and $2350 \pm 150 \mathrm{BC}$, and finally, a MP4 context to $1120 \pm 520 \mathrm{BC}$ (Bayard 2010a: 143).

Given these constraints, Bayard (2010a) battled to try and establish a chronological framework for the Non Nok Tha sequence. His final conclusions were that the Neolithic period began by the early third millennium $\mathrm{BC}$, perhaps the late fourth millennium, and lasted until the start of the Bronze Age some time after 2500 BC. The later Bronze Age burials, his MP4-5, were placed into the mid to late second millennium BC (Figure 2). This means that the cultural sequence from initial settlement to the end of the Bronze Age covered a period well in excess of 2000 years or, in human terms, at least 100 generations.

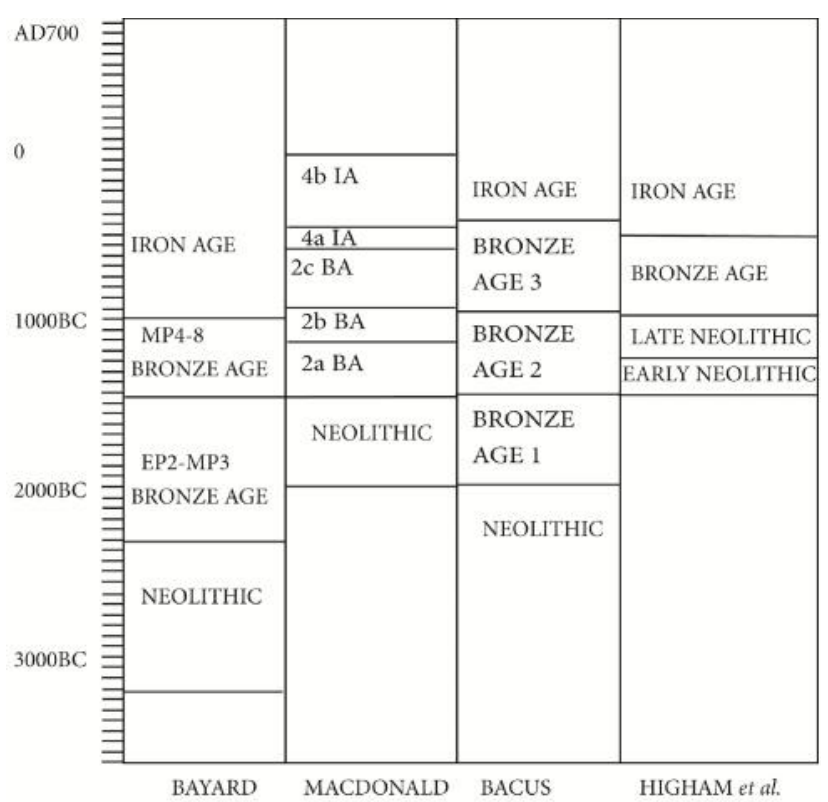

Figure 2: Chronologies that have been proposed for the cultural sequence at Non Nok Tha.

\section{Social interpretations}

For almost half a century there have been a series of social interpretations that judged the data in the context of millennial scales of social change. Bayard (2010b) reviewed the burials on the basis of the number of mortuary offerings and the degree to which these were obtained locally, or were exotic. These included ceramic vessels, bone tools, pig or bovine bones, stone axes, bivalve shells and shell beads. Bronzes comprised socketed axes, bracelets, stone bivalve moulds and crucibles. Bayard placed an arbitrary division at 15 offerings. Those above 15 were classified as wealthy and those below, poor. Through a series of statistical applications, he concluded that from the outset, there was a degree of ascriptive ranking, which increased markedly with the Bronze Age Middle Period. It was during the latter that he stressed a dichotomy between burials containing either vessel form $2 \mathrm{C}$ or $2 \mathrm{~L}$.
Finding that these were almost, but not completely, mutually exclusive, he suggested that members of the $2 \mathrm{C}$ group were the richer in terms of the overall quantum of grave goods, than those associated with pot form $2 \mathrm{~L}$. From this he concluded that Non Nok Tha during its Bronze Age phase was used as a cemetery, over a period of about 75 generations, by two distinct affiliative social groups residing, presumably in different settlements, in the general area.

MacDonald (1980) considered the Non Nok Tha mortuary and occupation data in order to identify the social organization and change over time. Faced with an almost insoluble problem of an internally contradictory set of radiocarbon and TL determinations, he applied a "one way analysis of variance" in order to "obtain the best estimate of dates within an archaeological component" (MacDonald 1980: 213). After eliminating a considerable number of outliers, he concluded that initial settlement took place in about $2000 \mathrm{BC}$. He then divided the cultural sequence into five phases. Phase 1 , which corresponds to Bayard's EP1-2, he dated from 2000-1500 BC. Phase 2 has three components (Figure 2). He placed 2a between 1500-1300 BC, phase $2 \mathrm{~b}$ from 1300-1000 BC and $2 \mathrm{c}$ from 1000-700 BC. Phase 3 is nebulous, while phase $4 \mathrm{a}$ he dated from 700-600 BC and $4 \mathrm{~b}$ from 600-0 BC. His interpretation assumed that Non Nok Tha was an occupation as well as a mortuary site.

Adopting five criteria for chiefdom societies advanced by Peebles and Kus (1977), MacDonald concluded that Non Nok Tha was a component of a centralized chiefdom during phase 2 from $1500-700 \mathrm{BC}$, and that there would have been many more in the general area at the same time. These variables included a marked settlement hierarchy, part time craft specialization and evidence for ascriptive ranking in the mortuary remains. MacDonald claimed evidence too, for increases in social complexity with phase $2 \mathrm{~b}$, reflected for example, on what he identified as craft specialization in producing wheel-thrown or mould-made pottery vessels. It is noted that pots made in moulds have also been found at $\mathrm{Ban} \mathrm{Na} \mathrm{Di}$, but with no associated claim for specialization (Higham and Kijngam 1984). MacDonald proceeded to suggest that with phase 4 , Non Nok Tha was then impinged upon by a state society located somewhere in the southern Khorat Plateau by about $1000 \mathrm{BC}$. He found evidence for increasing trade in exotica, and the beginnings of conflict.

Bacus (2006) has turned to Non Nok Tha as a vehicle to examine social organization during the Bronze Age with particular reference to gender relations. She divided the Bronze Age burials into early, middle and late phases. The chronological information available to her suggested that the early Bronze Age dated from 2000-1500 BC, the middle from 1500-1000 $\mathrm{BC}$ and the late period, from 1000-500 BC (Figure 2). She began her analyses by comparing male and female burials for each of three phases of the Bronze Age on the basis of the number of mortuary offerings with each individual. These were also considered in conjunction with the age of the deceased. Although she found possible distinctions in the wealth of 
individuals during early Bronze Age males on the basis of age, and again for at least one woman interred with 32 offerings, identifying significant status differences through all three phases proved elusive.

Bayard (1971) has reported the presence of mounds over some of the inhumation graves as well as ceramic vessels or sheets of broken potsherds in the grave fill or over the body. Bacus found that women were preferentially interred under mounds, and these were also accompanied by more mortuary offerings than those without. When incorporating these into her analyses, she concluded that during the early Bronze Age, women were according a greater degree of ritual when interred. Indeed, she found support for Bayard's suggestion that there was "institutionalized status inequality" (Bacus 2006:113). With the middle Bronze Age, she suggests that it was the placement of pottery vessels over the grave that distinguished the more highly ranked, with very few men receiving this special treatment.

\section{A NEW SERIES OF AMS RADIOCARBON DETERMINATIONS}

Resolving the chronology of Non Nok Tha has involved three chapters in the history of radiocarbon dating. The first saw the conventional counting of necessarily large samples of charcoal. This was greatly improved with the advent of AMS dating of much smaller samples and, at Non Nok Tha, it has been employed to date the organic fraction of ceramic tempers. We can now, however, employ two further advances in chronometric dating. First, the application of ultrafiltration to the dating of bone collagen from human remains (Brown et al., 1988; Higham et al., 2006). Second, the Bayesian analysis of calibrated determinations to refine the sequence and identify the beginning and end, and therefore the duration, of each cultural phase (Buck et al., 1996; Bronk Ramsey, 2001; Bayliss et al., 2007).

In reassessing the chronology of Non Nok Tha, we decided to apply improved radiocarbon dating of human bone by using ultrafiltration. All samples were prepared for AMS dating at the Oxford Radiocarbon Accelerator Unit (ORAU), University of Oxford. The ORAU applies an additional ultrafiltration step in the collagen extraction procedure based on Brown et al. (1988) (see Brock et al. [2010a] for current methods as applied here). An ultrafilter is a type of molecular sieve. It enables the separation of compounds, in this case polypeptide chains from the collagen, above and below a certain molecular weight cut off (MWCO). An undegraded collagen polypeptide chain from the procollagen triple-helix weighs 110 kiloDaltons $(\mathrm{kD})$, so we used a $30 \mathrm{kD}$ ultrafilter to allow particles larger than this to be retained above the filter. This includes the collagen-derived proteins. The method allows us to separate and discard the lower MWCO components below it using centrifugation. A measurably improved quality of collagen is produced.

We first sampled every available human skeleton from the 1966 and 1968 excavation seasons, and screened small (3-5 mg) sub-samples of drilled bone powder by measuring the elemental nitrogen concentration. Nitrogen is a proxy for protein, and therefore the amount of surviving collagen. Samples with $>\sim 0.6-0.7$ wt. $\% \mathrm{~N}$ were passed for full collagen extraction treatment (after Brock et al. 2010b) and AMS dating. This was around one third of the total number of bones that were tested. The remainder were low in $\mathrm{N}$ and therefore in collagen, averaging 0.3 wt. $\% \mathrm{~N}$. The Oxford preparative method included ultrafiltration treatment using precleaned Vivaspin $^{\mathrm{TM}} 30 \mathrm{kD}$ MWCO ultrafilters. The filtered collagen was freeze-dried and combusted in a CHN analyser linked in continuous flow mode to a Europa isotope ratio mass spectrometer using a helium carrier gas. We measured $\delta 15 \mathrm{~N}$ and $\delta 13 \mathrm{C}$ values, nitrogen and carbon content and also calculated the bone $\mathrm{C}: \mathrm{N}$ atomic ratios. $\mathrm{CO}_{2}$ from each combusted collagen sample was reduced over an iron catalyst in an excess $\mathrm{H}_{2}$ atmosphere at $560^{\circ} \mathrm{C}$ prior to AMS dating. Where bone collagen was <than 1 wt. \% collagen we denoted them with OxA-X- prefixes. We tested the reliability of dating bone with collagen yields of this size and the models showed that none were outliers. All other analytical parameters measured, including the carbon to nitrogen atomic ratio, were acceptable. We therefore consider the radiocarbon results to be robust and accurate AMS measurements.

Bayesian statistical modelling is based on a combination of calibrated radiocarbon determinations and 'prior' archaeological information usually in the form of relative age data. In the case of a mortuary site such as Non Nok Tha this is primarily rooted in the superposition of burials, the orientation of the graves, the disposition of a burial in a clearly conjoined context such as a nucleus or a row, and the typology of the mortuary offerings. It is not easy to generate such a sequence from incompletely published data from someone else's excavation, and this is particularly so for Non Nok Tha. There is, for example, no published catalogue containing each burial with associated mortuary offerings or the depth of skeleton or the grave cutting. Bayard has published a series of summaries that describe different sequences. The most fine-grained has three Neolithic and eight Bronze Age mortuary phases dovetailed from excavations that were several metres apart (Bayard 1971). He has also proposed three overall phases, being the Neolithic (EP1-3), the early Bronze Age (MP1-3) and the late Bronze Age (MP4-8) (Bayard 2010b: 406, Table 8), at the same time distinguishing between burials he regards as securely assigned to one of his 11 phases, and those he describes as insecure. To explore the ascription of each burial that has furnished a radiocarbon determination from human bone within the sequence we need to further scrutinize each skeleton within Bayard's sequence:

Burial 94 was partially covered by burial 111 of the early Bronze Age. It has two ceramic vessels of a form assigned to the early Neolithic. Bayard assigns it as securely EP1.

Burial 121 was not intercut or disturbed by another grave. It lay in row of four or five burials assigned to 
Table 1: Radiocarbon determinations of human bone from the Non Nok Tha site. OxA-X-prefixes are given in preference to OxAnumbers when there is a problem with the pre-treatment chemistry, AMS measurement or when there is a novel or experimental protocol applied in the dating. Date refers to the conventional radiocarbon age BP, after Stuiver and Polach (1977). Errors are the determined standard errors (values are \pm one standard error). 'Used' represents the amount of bone powder pretreated in milligrams. Yield is the weight of collagen or ultrafiltered collagen in milligrams, while yield (\%) is the percent yield of extracted collagen as a function of the starting weight of the bone analysed. \%C is the carbon present in the combusted collagen. Stable isotope ratios are expressed in $\%$ relative to $v P D B$ with a mass spectrometric precision of $\pm 0.2 \%$ for $C$ and $\pm 0.3 \%$ for $N$. C: $N$ is the atomic ratio of $C$ to $N$ and is acceptable if it ranges between 2.9-3.5. * denote determinations that were not ultrafiltered, these were gelatinised only.

\begin{tabular}{|c|c|c|c|c|c|c|c|c|c|}
\hline OxA/OxA-X & $\begin{array}{l}\text { Radiocarbon age } \\
\text { BP }\end{array}$ & \pm value & $\begin{array}{l}\text { Used } \\
\text { (mg) }\end{array}$ & $\begin{array}{l}\text { Collagen Yield } \\
(\mathrm{mg})\end{array}$ & $\%$ Yld & $\% \mathrm{C}$ & $\begin{array}{l}\delta^{13} \mathrm{C} \\
(\% \circ)\end{array}$ & $\begin{array}{l}\delta^{15} \mathrm{~N} \\
(\% \circ)\end{array}$ & $\mathrm{CN}$ \\
\hline $2586-15$ & 2570 & 27 & 1020 & 3.72 & 0.4 & 42.3 & -19.0 & 12.3 & 3.4 \\
\hline $2586-16$ & 2505 & 31 & 1040 & 3.58 & 0.3 & 40.8 & -18.3 & 12.1 & 3.4 \\
\hline $2586-17$ & 3146 & 30 & 960 & 2.61 & 0.3 & 43 & -19.5 & 14.8 & 3.4 \\
\hline $2586-19$ & 3102 & 30 & 1010 & 3.07 & 0.3 & 39.7 & -19.5 & 13.0 & 3.5 \\
\hline $2586-20$ & 2564 & 30 & 910 & 3.36 & 0.4 & 41.1 & -19.5 & 14.3 & 3.4 \\
\hline $2524-20^{*}$ & 2669 & 27 & 1530 & 19.02 & 1.2 & 26.1 & -11.5 & 6.6 & 3.4 \\
\hline $2524-21^{*}$ & 2717 & 25 & 1610 & 20.78 & 1.3 & 25.9 & -19.5 & 10.7 & 3.4 \\
\hline 30360 & 2911 & 27 & 1140 & 14.9 & 1.3 & 41.9 & -18.9 & 12.7 & 3.2 \\
\hline 30361 & 2879 & 26 & 1100 & 9.81 & 0.9 & 41.3 & -19.1 & 11.4 & 3.2 \\
\hline 30391 & 2414 & 27 & 1020 & 6.09 & 0.6 & 40.4 & -19.3 & 11.0 & 3.3 \\
\hline 30392 & 3059 & 28 & 990 & 10.49 & 1.1 & 41.7 & -19.3 & 11.7 & 3.4 \\
\hline 30393 & 2473 & 27 & 1040 & 10.06 & 1 & 41.1 & -18.9 & 11.5 & 3.3 \\
\hline 30394 & 2566 & 27 & 1020 & 29.05 & 2.8 & 41.8 & -18.7 & 10.7 & 3.3 \\
\hline 30395 & 2536 & 28 & 1030 & 8.07 & 0.8 & 40.5 & -19.2 & 10.3 & 3.3 \\
\hline 30396 & 3028 & 28 & 1080 & 17.82 & 1.7 & 41.3 & -19.1 & 12.5 & 3.3 \\
\hline 30644 & 2788 & 29 & 1000 & 10.28 & 1 & 41.9 & -19.2 & 10.8 & 3.3 \\
\hline
\end{tabular}

Table 2. The AMS radiocarbon determinations for Non Nok Tha from human bone.

\begin{tabular}{|c|c|c|c|c|c|c|}
\hline $\begin{array}{l}\text { Laboratory } \\
\text { code }\end{array}$ & $\begin{array}{l}\text { Sample } \\
\text { human bone }\end{array}$ & Period & $\begin{array}{l}\delta^{13} \mathrm{C} \\
(\% \circ)\end{array}$ & $\begin{array}{l}\text { Radiocarbon Age } \\
\text { (BP) }\end{array}$ & $\begin{array}{l}\text { Calibr } \\
\text { (95.4 } \\
\text { From }\end{array}$ & $3 C$ \\
\hline OxA-X-2586-17 & burial 94 & EP1 & -19.49 & $3146 \pm 30$ & 1499 & 1309 \\
\hline OxA-X-2586-18 & burial 94 & EP1 & -19.49 & $3102 \pm 30$ & 1432 & 1286 \\
\hline OxA-30360 & burial 121 & EP2 & -18.95 & $2911 \pm 27$ & 1207 & 1015 \\
\hline OxA-30361 & Burial 78 & EP2 & -19.06 & $2879 \pm 26$ & 1189 & 943 \\
\hline OxA-30396 & burial 35 & EP2 & -19.08 & $3028 \pm 28$ & 1394 & 1196 \\
\hline OxA-30392 & burial 29 & EP2 & -19.27 & $3059 \pm 28$ & 1409 & 1232 \\
\hline OxA-X-2524-21 & burial $62^{*}$ & MP2 & -19.50 & $2717 \pm 25$ & 909 & 814 \\
\hline OxA-X-2524-20 & burial 38* & MP3 & -11.50 & $2669 \pm 27$ & 895 & 798 \\
\hline OxA-X-2586-15 & burial 85 & MP4 & -19.01 & $2570 \pm 27$ & 808 & 590 \\
\hline OxA-30395 & burial 55 & MP4 & -19.15 & $2536 \pm 28$ & 797 & 548 \\
\hline OxA-X-2586-16 & burial 80 & MP4 & -18.32 & $2505 \pm 31$ & 788 & 540 \\
\hline OxA-30393 & burial 7 & MP4 & -18.93 & $2473 \pm 27$ & 770 & 433 \\
\hline OxA-30394 & burial 17 & MP5 & -18.68 & $2566 \pm 27$ & 806 & 568 \\
\hline OxA-30391 & burial 24 & MP6 & -19.35 & $2414 \pm 27$ & 735 & 403 \\
\hline $\begin{array}{l}\text { OxA-X-2586-19 } \\
{ }^{*} 1996 \text { excavation season }\end{array}$ & burial 1 & MP6 & -19.52 & $2564 \pm 30$ & 806 & 555 \\
\hline
\end{tabular}




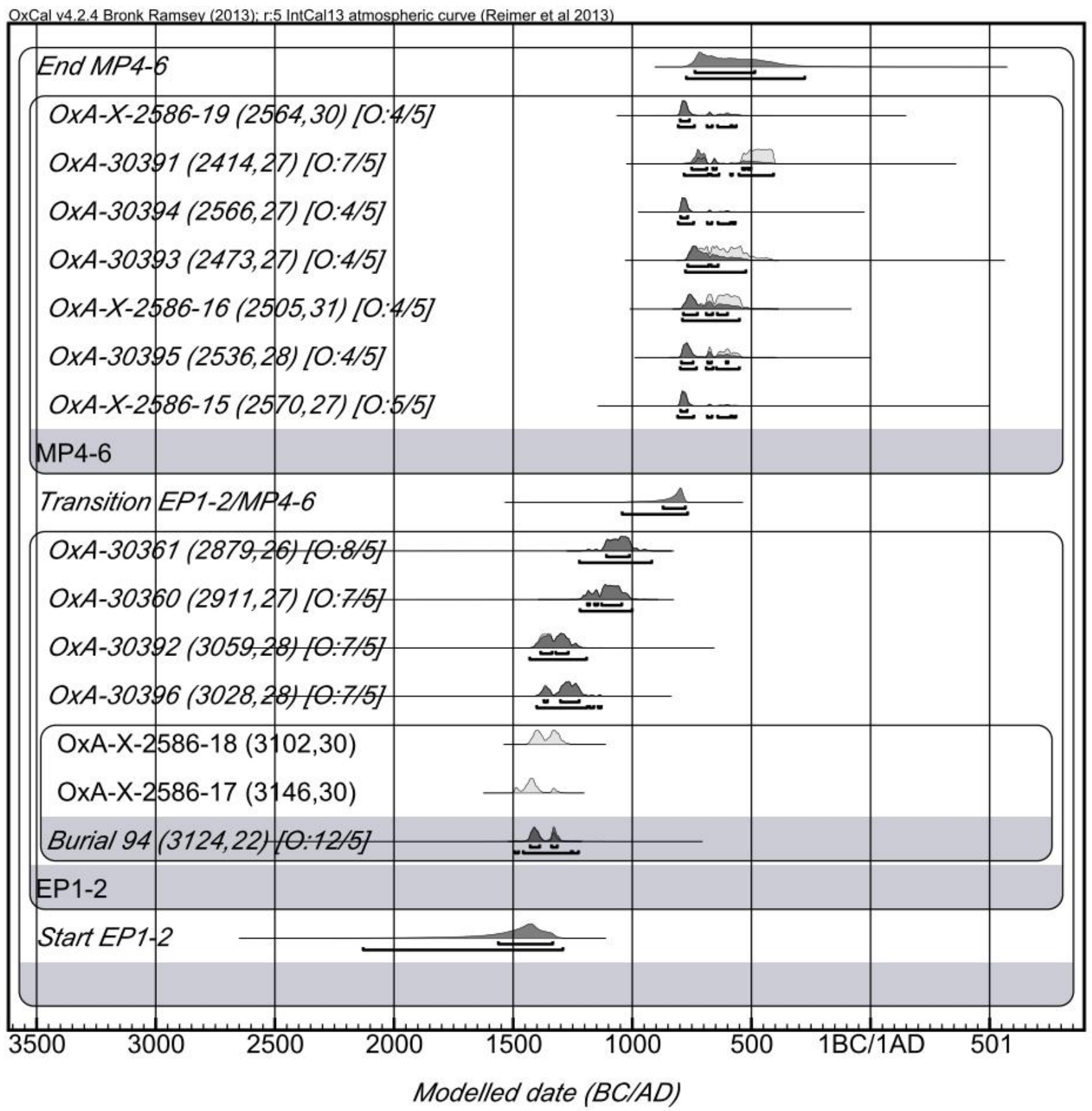

Figure 3: Bayesian model showing probability distributions of results relating to the cultural sequence of Non Nok Tha (OxCal v4.0.5 Bronk Ramsey (2001); r:5 IntCal04 atmospheric curve (Reimer et al. 2004)).

EP2, and contained pottery vessels typical of the Neolithic occupation. It was assigned securely to EP2.

Burial 78 was stratified under burials assigned to EP3 and MP6. No grave goods were identified. It lay on the same orientation as three EP1 burials, and was assigned securely to EP2.

Burial 29 was partly disturbed by a burial assigned to MP1, the early Bronze Age. It lay in a row of graves assigned to EP2, and contained three pots of Neolithic form. Bayard assigned it with confidence to EP2.

For burial 35 Bayard assigned it insecurely to MP4, the late Bronze Age. It does not intercut any other grave. However, it lies in a row with four EP2 burials and on the same orientation. It also contained a form $1 \mathrm{G}$ pottery vessel. This form was commonly found in Early Period Neolithic contexts, there being 29 pots from 25 secure EP burials. However, only five were recovered from 38 secure Bronze Age graves. This burial is therefore assigned to EP2.

Burial 62 of the 1966 season was insecurely assigned to MP2. It was not intercut by any other grave, but contained a $2 \mathrm{D}$ pot, a form never found with a secure Neolithic burial, only with those of the Bronze Age.

Burial 38 of the 1966 season was assigned tentatively to MP3. It contained five pottery vessels that occur in Bronze Age contexts. 


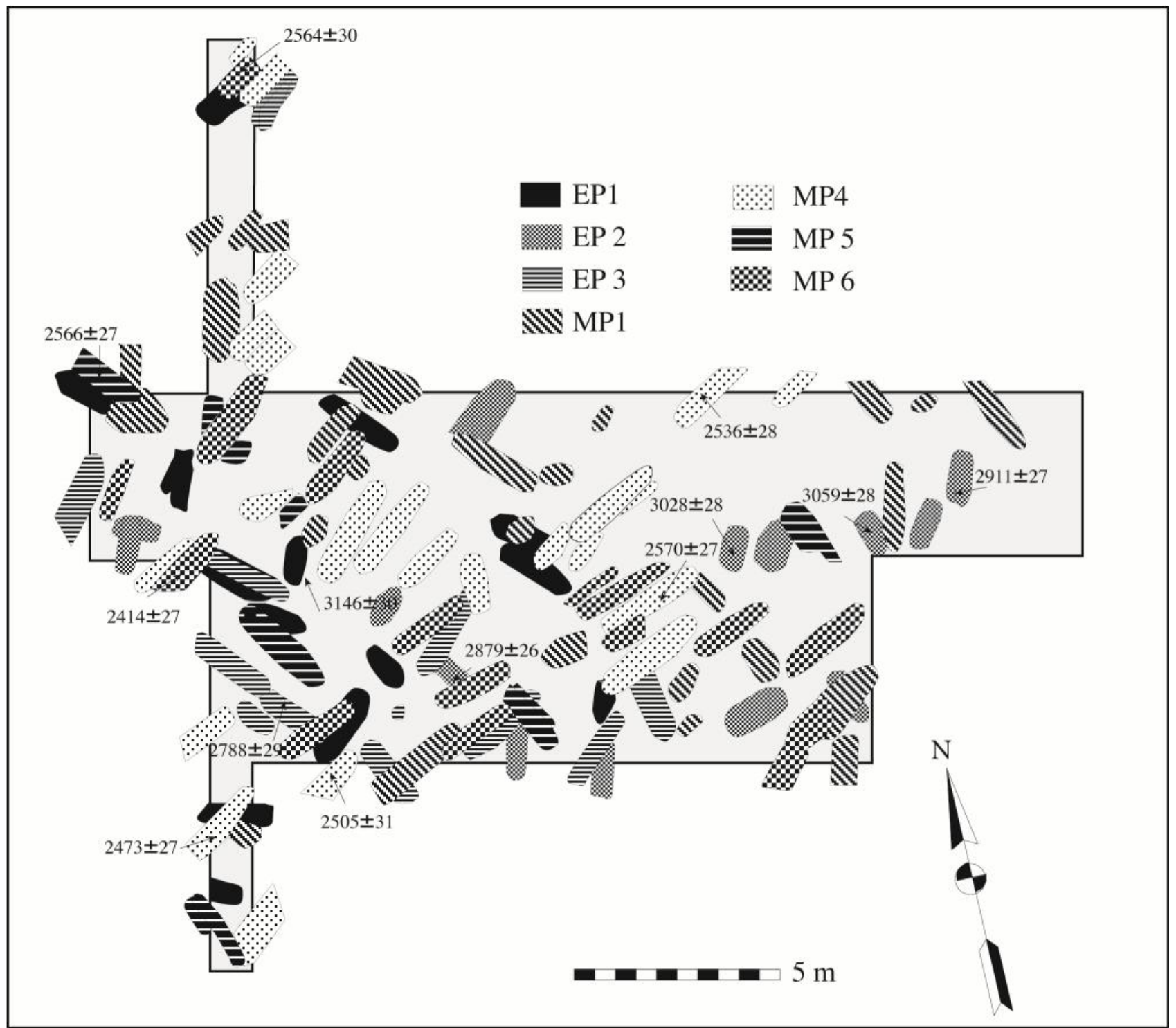

Figure 4: The mortuary plan for Non Nok Tha 1968 showing burials from each phase, and the associated radiocarbon determinations $(B P)$.

Burial 85 is described by Bayard as insecurely in MP4. It is definitely Bronze Age given the presence of a bronze axe as a mortuary offering, and pots that are regularly found with other Bronze Age burials. It lies under burial 70, insecurely assigned to MP6, and cuts into burial 75, which was insecurely assigned to MP1.

Burial 55 is insecurely assigned to MP4. It lies alone, with no intercutting, but contained typical Bronze Age pottery vessels.

Burial 80 is insecurely assigned to MP4. It lies over an EP1 burial. There are no diagnostic offerings, but it does lie on the same orientation as the majority of MP4 burials.

Burial 7 is insecurely assigned to MP4. It overlies an EP1 grave, and cuts into one assigned to MP1. Pottery vessels in association are Bronze Age in form.
Burial 17 is insecurely assigned to MP5. It overlies burials ascribed to EP1 and MP1. A $2 \mathrm{~L}$ pot in the grave is typical of the Bronze Age.

Burial 24 is insecurely assigned to MP6. It overlies, and there is therefore later, than burials assigned to EP1, EP3 and MP4.

Burial 1 is insecurely assigned to MP6. It overlies burials of EP1 and MP4. The pottery vessels associated are typical of the Bronze Age.

In general then, the association of many burials to particular mortuary 'phases' of occupation at the site is not supported with confidence. The sequence consists essentially of two broad periods or phases, the first of which is the Neolithic (Bayard's EP1-3) and the second the Bronze Age, being the Middle Period. The validity of this broad subdivision is supported by the marked distinction between the two on the basis of ceramic typology, the presence of bronze grave goods in the MP graves, and the fact 
Table 3: The mortuary offerings placed with adults in the Neolithic cemeteries of Ban Non Wat, Non Nok Tha and Ban Lum Khao. SB: shell bangle, GS: grinding stone, BS: bivalve shell, SA: stone adze.

\begin{tabular}{|c|c|c|c|c|c|c|c|c|c|c|c|c|c|c|}
\hline Site & Burial & Sex & Age & Pots & SA & $\begin{array}{l}\text { Pig } \\
\text { bone }\end{array}$ & $\begin{array}{l}\text { Cattle } \\
\text { bone }\end{array}$ & $\begin{array}{l}\text { Fish } \\
\text { bone }\end{array}$ & BS & GS & $\begin{array}{l}\text { Shell } \\
\text { bead }\end{array}$ & SB & $\begin{array}{l}\text { Cowrie } \\
\text { shell }\end{array}$ & $\begin{array}{l}\text { Bronze } \\
\text { Axe }\end{array}$ \\
\hline \multirow[t]{17}{*}{ BNW } & 15 & - & YA & 4 & 0 & 0 & 0 & 0 & 0 & 0 & 0 & 0 & 0 & 0 \\
\hline & 16 & $\mathrm{~F}$ & YMA & 9 & 1 & 0 & 0 & 0 & 0 & 0 & 0 & 0 & 0 & 0 \\
\hline & 27 & - & A & 1 & 0 & 0 & 0 & 0 & 0 & 0 & 0 & 0 & 0 & 0 \\
\hline & 28 & M & MOA & 3 & 0 & 0 & 0 & 0 & 1 & 0 & 0 & 0 & 0 & 0 \\
\hline & 32 & - & MOA & 2 & 0 & 0 & 0 & 0 & 2 & 0 & 0 & 0 & 0 & 0 \\
\hline & 86 & $M$ & Y & 4 & 0 & 3 & 0 & 9 & 3 & 0 & 0 & 0 & 2 & 0 \\
\hline & 191 & - & A & 3 & 0 & 1 & 0 & 0 & 0 & 0 & 0 & 0 & 0 & 0 \\
\hline & 242 & $\mathrm{~F}$ & A & 0 & 0 & 0 & 0 & 0 & 0 & 0 & 0 & 0 & 0 & 0 \\
\hline & 249 & $\mathrm{~F}$ & - & 0 & 0 & 0 & 0 & 0 & 0 & 0 & 0 & 0 & 0 & 0 \\
\hline & 250 & M & $O A$ & 3 & 0 & 1 & 0 & 0 & 0 & 0 & 1 & 0 & 0 & 0 \\
\hline & 255 & $M$ & YA & 0 & 0 & 0 & 0 & 0 & 0 & 0 & 0 & 0 & 0 & 0 \\
\hline & 264 & M & YA & 2 & 1 & 2 & 0 & 0 & 0 & 0 & 0 & 0 & 0 & 0 \\
\hline & 286 & $\mathrm{~F}$ & YA & 0 & 0 & 0 & 0 & 0 & 0 & 0 & 0 & 0 & 0 & 0 \\
\hline & 289 & - & A & 2 & 1 & 1 & 0 & 0 & 0 & 0 & 0 & 0 & 0 & 0 \\
\hline & 292 & $\mathrm{~F}$ & MA & 2 & 0 & 0 & 0 & 0 & 1 & 0 & 0 & 1 & 5 & 0 \\
\hline & 459 & - & - & 1 & 0 & 0 & 0 & 0 & 0 & 0 & 0 & 0 & 0 & 0 \\
\hline & & & & & & & & 0 & & & & & & \\
\hline \multirow{10}{*}{ NNT } & $\begin{array}{l}6 \\
4\end{array}$ & $\begin{array}{l}\mathrm{M} \\
\mathrm{F}\end{array}$ & $\begin{array}{l}30 y \\
33\end{array}$ & $\begin{array}{l}9 \\
8\end{array}$ & $\begin{array}{l}2 \\
8\end{array}$ & $\begin{array}{l}0 \\
0\end{array}$ & $\begin{array}{l}0 \\
0\end{array}$ & $\begin{array}{l}0 \\
0\end{array}$ & $\begin{array}{l}0 \\
0\end{array}$ & $\begin{array}{l}1 \\
0\end{array}$ & $\begin{array}{l}2 \\
0\end{array}$ & $\begin{array}{l}0 \\
0\end{array}$ & $\begin{array}{l}0 \\
0\end{array}$ & $\begin{array}{l}0 \\
0\end{array}$ \\
\hline & 62 & $M$ & 33 & 2 & 0 & 1 & 0 & 0 & 0 & 2 & 0 & 0 & 0 & 0 \\
\hline & 65 & - & - & 3 & 0 & 0 & 0 & 0 & 0 & 0 & 0 & 0 & 0 & 0 \\
\hline & 83 & $\mathrm{~F}$ & 25 & 5 & 1 & 0 & 0 & 0 & 0 & 0 & 0 & 0 & 0 & 0 \\
\hline & 126 & - & - & 2 & 1 & 0 & 0 & 0 & 0 & 0 & 0 & 0 & 0 & 0 \\
\hline & 78 & $\mathrm{~F}$ & 33 & 0 & 0 & 0 & 0 & 0 & 0 & 0 & 0 & 0 & 0 & 0 \\
\hline & 10 & $M$ & 20 & 2 & 0 & 1 & 1 & 0 & 0 & 0 & 0 & 0 & 0 & 0 \\
\hline & 52 & - & 43 & 1 & 0 & 1 & 0 & 0 & 1 & 0 & 0 & 0 & 0 & 0 \\
\hline & 79 & $\mathrm{~F}$ & 20 & 2 & 0 & 0 & 0 & 1 & 0 & 0 & 0 & 0 & 0 & 0 \\
\hline & 90 & $M$ & 40 & 7 & 0 & 2 & 0 & 0 & 0 & 0 & 0 & 0 & 0 & 1 \\
\hline \multirow[t]{8}{*}{ BLK } & 30 & M & $30-34$ & 5 & 0 & 1 & 0 & 0 & 0 & 0 & 786 & 0 & 0 & 0 \\
\hline & 44 & $M$ & $30-39$ & 3 & 0 & 0 & 0 & 0 & 1 & 0 & 0 & 0 & 0 & 0 \\
\hline & 64 & $\mathrm{~F}$ & $40-44$ & 10 & 0 & 0 & 0 & 0 & 0 & 0 & 0 & 1 & 0 & 0 \\
\hline & 71 & $\mathrm{M}$ & $20-29$ & 1 & 0 & 0 & 0 & 0 & 0 & 0 & 0 & 0 & 0 & 0 \\
\hline & 72 & $\mathrm{~F}$ & $20-24$ & 1 & 0 & 0 & 0 & 0 & 0 & 0 & 1 & 0 & 0 & 0 \\
\hline & 92 & $\mathrm{~F}$ & $20-29$ & 2 & 0 & 1 & 0 & 0 & 0 & 0 & 0 & 0 & 0 & 0 \\
\hline & 93 & M & $40-44$ & 2 & 0 & 0 & 0 & 0 & 0 & 0 & 0 & 0 & 0 & 0 \\
\hline & 98 & $\mathrm{~F}$ & $40+$ & 2 & 0 & 0 & 0 & 0 & 0 & 0 & 0 & 0 & 0 & 0 \\
\hline
\end{tabular}

Table 4: The number of mortuary offerings for all graves during the Bronze Age at Non Nok Tha and Bronze Age phases 2-3A at Ban Non Wat.

\begin{tabular}{lll}
\hline Item & $\begin{array}{l}\text { Non Nok Tha } \\
\mathrm{n}=53 \text { graves }\end{array}$ & $\begin{array}{l}\text { Ban Non Wat } \\
\mathrm{n}=45 \text { graves }\end{array}$ \\
\hline Pottery vessel & 350 & 1003 \\
Shell disc beads & 1170 & 234,926 \\
Shell bracelet & 4 & 742 \\
Bone tool & 8 & 0 \\
Stone adze & 2 & 2 \\
Bronze Axe & 3 & 15 \\
Axe mould & 1 & 0 \\
Crucible & 2 & 0 \\
Red ochre & 8 & 4 \\
Cattle bone & 27 & 31 \\
Pig bone & 14 & 70 \\
Bivalve shell & 13 & 5 \\
Whetstone & 22 & 5 \\
Bronze chisel & 0 & 2 \\
Bronze awl & 0 & 55 \\
Bronze bell & 0 & 43 \\
Marble bangle & 0 & 116 \\
Fish & 0 & 53 \\
Shell earrings & 0 & 3 \\
Marble earrings & 0 & \\
\hline
\end{tabular}

that where there is intercutting, the Bronze Age graves always overlie, and are thus later than, the Neolithic burials. Although all of the Bronze Age burials are deemed insecure by Bayard when attempting to assign them to one of his six Middle Period phases, there is no argument that there is indeed a transition from the Neolithic use of the cemetery into that following the adoption of copperbase metallurgy. In terms of Bayesian priors then, we are restricted in terms of largely 'uninformative' priors in the case of this site.

Three other sites on the Khorat Plateau have the same sequence: Ban Chiang, Ban Lum Khao and Ban Non Wat. All three have recently provided third generation dated sequences. At Ban Non Wat, the initial Neolithic settlement has been dated in the $17^{\text {th }}$ century $\mathrm{BC}$, while the transition into the Bronze Age took place between 10501000 BC (Higham and Higham 2009). Debating the chronology of Ban Chiang has run in parallel with Non Nok Tha. White and Hamilton (2009) argue that third millennium BC Neolithic occupation at Ban Chiang leads to a transition into the Bronze Age between 2000-1800 BC. This sequence, however, is based on second generation dating of organic ceramic tempers mixed with clay, which 


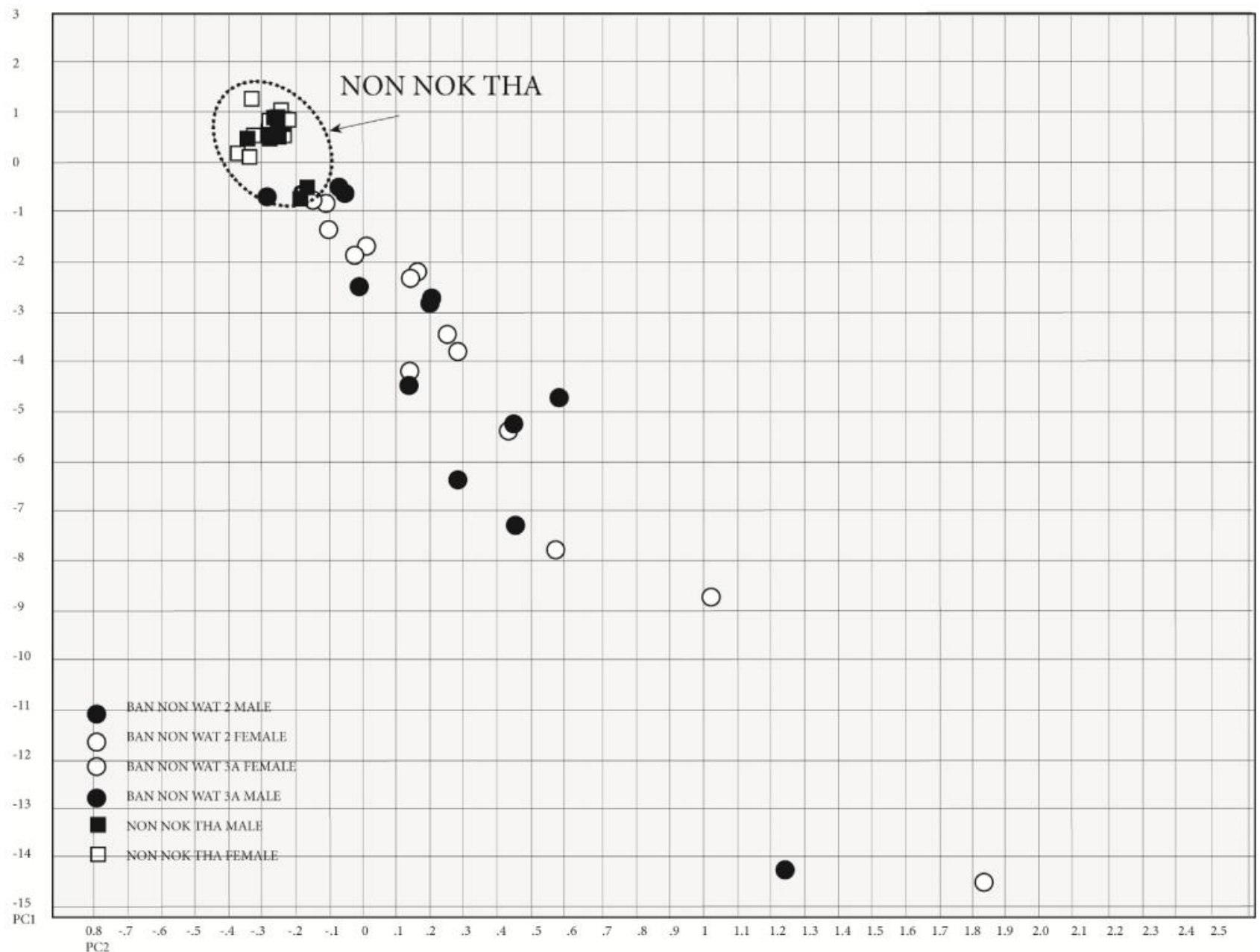

Figure 5: The results of a principal component analysis for all adult Bronze Age graves from Non Nok Tha and Ban Non Wat mortuary phases 2 and $3 A$.

is liable to furnish spuriously early results (Higham et al. 2011). Consequently, ultrafiltered human bone collagen from this site has been AMS dated, showing initial Neolithic settlement in the $16^{\text {th }}$ century $\mathrm{BC}$, with the earliest Bronze Age burials placed from about 1000 BC (Higham et al. 2011). This not only presents a neat correlation with the Ban Non Wat chronology, but it compresses the duration of the Bronze Age and therefore involves a much faster pace of any cultural change. The radiocarbon determinations from Neolithic contexts at Ban Lum Khao are late $2^{\text {nd }}$ millennium $\mathrm{BC}$, the Bronze Age dates are later than $1000 \mathrm{BC}$ (Higham et al. 2015).

We have found that the same situation obtains from Non Nok Tha. Burial 94, which represents EP1, the earliest mortuary phase, has been dated to the mid-14 ${ }^{\text {th }}$ century BC (Tables $1 \& 2$, Figure 3). EP 2, the second Neolithic mortuary phase, ended in the mid $-11^{\text {th }}$ century. There are no determinations for EP3, the phase with the earliest socketed copper base axe, but is nevertheless placed in the interval between EP2 and the determination for MP $1 / 2$ from 1966 season burial 62 (cal. $901 \pm 37$ BC). Burial 38 from 1966 MP3 is dated in the $9^{\text {th }}$ century BC, while 1968 season MP4-6 results are virtually identical, falling in the $8^{\text {th }}$ century BC (Figure 4$)$.

Non Nok Tha thus falls into line with other sites dated by the ultrafiltration of human bones or the bivalve shells placed with the dead. Two major periods of mortuary activity are represented. EP1-2 are Neolithic, and date in the last four centuries of the $2^{\text {nd }}$ millennium BC. EP3 is mainly Neolithic, but one late burial in this phase contained a bronze socketed axe of a form closely paralleled in the first Bronze Age phase at Ban Non Wat, where it is dated to about $1000 \mathrm{BC}$. There was then a marked change in the form of the pottery vessels placed with the dead during a relatively brief period, measured in three or four centuries, when the site was used as a Bronze Age cemetery and mortuary offerings included a modest quantity of bronze mortuary offerings and associated bivalve moulds and crucibles.

\section{DISCUSSION: IMPLICATIONS OF THE NEW CHRONOLOGICAL FRAMEWORK.}

\section{The Neolithic Period}

There are only three Neolithic sites on the Khorat Plateau that provide published evidence for the mortuary traditio- 
Table 5: The number of mortuary offerings placed with individuals interred under mounds at Non Nok Tha. TG: total number of mortuary offerings, TP: total number of pottery vessels.

\begin{tabular}{|c|c|c|c|c|c|c|c|c|c|c|c|c|c|}
\hline Year & Burial & Period & Sex & Age & TG & TP & Year & Burial & Per. & Sex & Age & TG & TP \\
\hline 1966 & 6 & EP1 & $\mathrm{M}$ & 30 & 15 & 6 & 1968 & 125 & EP1 & C & 5 & 9 & 4 \\
\hline 1968 & 126 & EP1 & & & 3 & 2 & 1966 & 109 & EP2 & & & 4 & 2 \\
\hline 1968 & 112 & EP2 & & & 15 & 7 & & & & & & & \\
\hline 1966 & 21 & E/MP1 & & & 2 & 2 & 1966 & 80 & E/MP1 & & & 3 & 3 \\
\hline 1966 & 8 & MP1 & $F$ & 42 & 35 & 21 & 1966 & 2 & MP2 & $F$ & $A D$ & 13 & 8 \\
\hline 1966 & 13 & MP2 & & & 9 & 8 & 1966 & 20 & MP2 & & & 16 & 9 \\
\hline 1966 & 28 & MP2 & $F$ & 30 & 10 & 4 & 1966 & 59 & MP2 & $F$ & 42 & 11 & 8 \\
\hline 1966 & 77 & MP2 & M & 42 & 17 & 10 & 1968 & 101 & MP1 & & & 4 & 3 \\
\hline 1968 & 103 & MP1 & $\mathrm{F}$ & 33 & 26 & 12 & 1968 & 107 & MP1 & & & 5 & 2 \\
\hline 1968 & 113 & MP1 & & & 8 & 5 & 1968 & 114 & MP1 & & & 14 & 9 \\
\hline 1968 & 119 & MP1 & & & 8 & 7 & 1968 & 120 & MP1 & & & 14 & 11 \\
\hline 1968 & 123 & MP1 & & & 13 & 9 & 1968 & 127 & MP1 & & & 10 & 9 \\
\hline 1966 & 3 & MP1 & & & 2 & 2 & 1966 & 25 & MP1 & & & 10 & 7 \\
\hline 1966 & 30 & MP1 & $F$ & YO & 8 & 5 & 1966 & 68 & MP1 & & & 5 & 5 \\
\hline 1966 & 70 & MP1 & & & 8 & 8 & 1966 & 82 & $\mathrm{MP} 1 / 2$ & & & 2 & 2 \\
\hline 1966 & 83 & MP1/2 & $\mathrm{C}$ & & 7 & 7 & 1966 & 84 & $\mathrm{MP} 1 / 2$ & & & 0 & 1 \\
\hline 1968 & 104 & MP1 & & & 11 & 4 & 1968 & 105 & MP1 & & & 5 & 4 \\
\hline 1968 & 108 & MP1 & $M$ & $A D$ & 4 & 3 & 1968 & 115 & MP1 & & & 3 & 2 \\
\hline 1968 & 116 & MP1 & & 16 & 12 & 11 & 1968 & 118 & MP1 & & & 11 & 8 \\
\hline 1966 & 32 & MP2 & $\mathrm{M}$ & $A D$ & 4 & 2 & 1966 & 29 & MP2 & & & 1 & 0 \\
\hline 1966 & 62 & MP2 & $F$ & YA & 4 & 3 & 1968 & 106 & MP1 & & & 0 & 0 \\
\hline
\end{tabular}

ns: Non Nok Tha, Ban Non Wat and Ban Lum Khao (Higham and Thosarat 2005, Higham and Kijngam 2012). The revised chronology for Non Nok Tha makes necessary a reconsideration of earlier interpretations of the mortuary record. In all those, and that which follows, the assessment of social rank and change with time is rooted in the quantity and the quality of offerings placed with the dead and, where possible, less tangible indications of the rites of passage that accompanied burial.

Table 3 provides the range and quantities of ritual offerings placed with the adult dead in the three relevant sites. The corpse was nearly always interred supine, and ceramic vessels dominate the grave goods. There were also stone adzes, grinding stones, bivalve shells, shell disc bead and pig and shell bracelets, fish bones and exotic cowries. Many of the adults at the three sites were interred with a handful of pottery vessels. Beyond these, offerings were parsimonious. Just two burials at Ban Non Wat were interred with undoubted exotic ornaments in the form of marine cowrie shells. Most of the infants from Ban Non Wat and Ban Lum Khao were buried in lidded ceramic vessels with virtually no other offerings.

Bayard (2010b: 411) has suggested that the child burial 14 at Non Nok Tha was unusually rich. It was found with the bones taken from a bovid and two pigs, together with six ceramic vessels, a bivalve shell, some shell disc beads and a bone tool. Where Bayard finds evidence for a disparity in wealth among the Non Nok Tha Neolithic, we are more impressed by their relative poverty that is matched at the other two sites in question. Some of the Non Nok Tha mortuary vessels were decorated with incised and impressed designs, and others were decorated with red paint. The incised and impressed ornamentation is a widespread marker of the early Neolithic in Southeast Asia. It was also found at Ban Non Wat, but the forms of the ceramic vessels and the complexity of their painted designs were markedly more complex than those found at Non Nok Tha.

\section{The Bronze Age}

As with the Neolithic record, social organization during the Bronze Age settlements on the Khorat Plateau is deduced from the mortuary record. Bayard, MacDonald and Bacus all concluded that there was evidence for ascribed social ranking during the Bronze Age at Non Nok Tha. For Bayard, there were two affiliated groups distinguished by a wealthy set with $2 \mathrm{C}$ pots and a poor group with $2 \mathrm{~L}$ vessels. MacDonald had Non Nok Tha as a component of a chiefdom a century before, as we now know, it was settled by the first Neolithic community. Bacus identified rich individuals on the basis of the presence of mounds and the quantum of mortuary offerings. All three set the Bronze Age within a chronological context of well over a millennium.

For Non Nok Tha, we have only the mortuary record and the third generation chronology to turn to in reexamining this issue. However, much new information on the Bronze Age on the Khorat Plateau has become available through the excavation of Ban Non Wat and Ban Lum Khao (Higham and Thosarat 2005, Higham and Kijngam 2012). Table 4 presents the total number of mortuary offerings from all securely provenanced adult graves at Non Nok Tha, compared with those from Ban Non Wat Bronze Age phases 2 and 3A. The detailed reports on the early Bronze Age rituals at the latter site describe a phenomenal surge in mortuary wealth, measured not only in the number and quality of the ceramic vessels placed with the dead, but also the weight of exotic ornaments worn by the deceased (Higham 2011). Thus, the four shell bracelets with 53 individuals at Non Non Tha must be compared with 742 marine shell bracelets from 45 individuals at Ban Non Wat. No exotic marble bracelets were found 
at Non Nok Tha, but 43 were recovered at Ban Non Wat. Five times as many copper-base axes come from Ban Non Wat compared with Non Nok Tha, a site that also provided awls, bells, anklets and chisels. Non Nok Tha, however, had all the bronze bracelets. If as is thought possible, bivalve shells and red ochre represent fertility and rebirth, then the mortuary rituals at Ban Non Wat must have been much more intense than at Non Nok Tha. The food remains from Ban Non Wat include many complete fish, as well as pig bones, whereas cattle were preferred at Non Nok Tha. The many pot forms and food remains at Ban Non Wat have suggested that mortuary feasting the dead was a key rite of passage, and a vehicle to project the social standing of the sponsors (Higham 2011). If so, then the wealth and social status of the dominant lineage at Ban Non Wat must have been in a different league to those at Non Nok Tha. Based on the mortuary rituals, there are prima facie grounds to propose a dramatic rise in social inequality at Ban Non Wat, but relative poverty at Non Nok Tha.

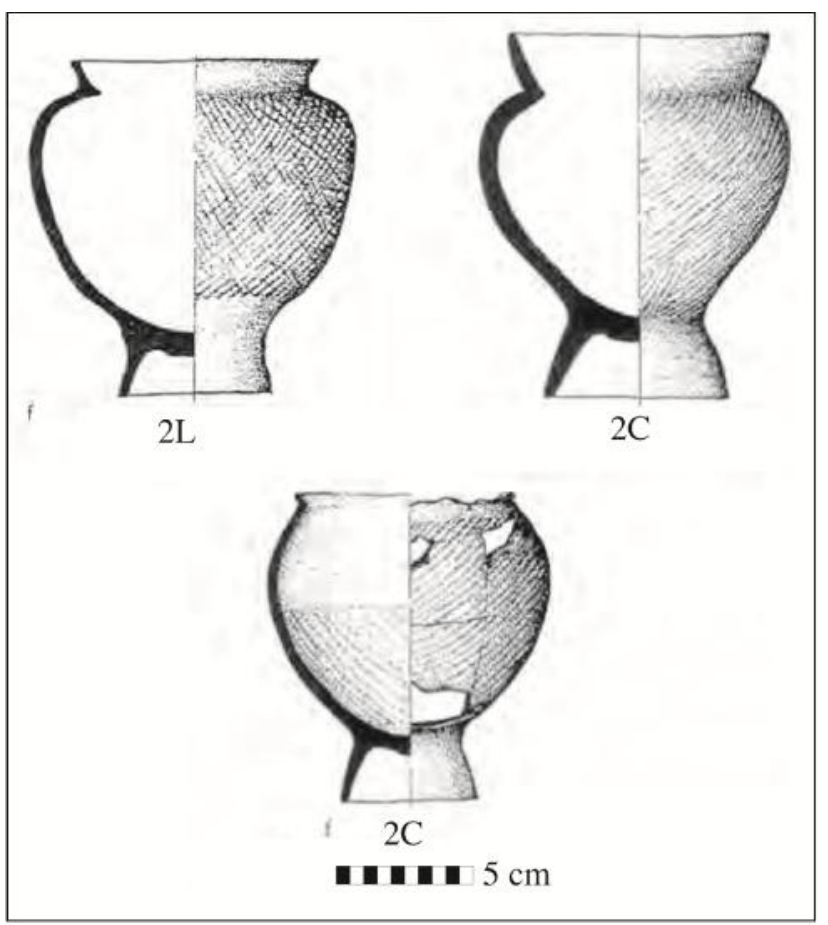

Figure 6: Ceramic forms $2 C$ and $2 L$ from Middle Period Non Nok Tha.

This may be evaluated by the application of a principal component analysis (PCA) which compares the two sites on the basis of the quantity of mortuary offerings placed with the dead. For Ban Non Wat, the sample comprises the BA 2 and $3 \mathrm{~A}$ adults, compared with all the Bronze Age graves at Non Nok Tha. The PCA distribution for the adult burials from Ban Non Wat during BA 2 and $3 \mathrm{~A}$ reveal a massive contrast compared with the tight nucleus of those from Non Nok Tha (Figure 5). There is barely any overlap between the two sites, nor any compelling evidence for a social divide at Non Nok Tha.

Given this situation, a reinterpretation of some of Bayard's results seems necessary. He drew a distinction between the graves with $2 \mathrm{C}$ or $2 \mathrm{~L}$ ceramic vessels. His illustration of these two forms is reproduced in Figure 6. The differences between the two are few and subtle: unidirectional against cross-hatched cord marking, and slight variations in rim form. The former were usually made on a mould with the foot and rim added, there is less evidence for moulding for the $2 \mathrm{~L}$ form. The differences in the wealth of $2 \mathrm{C}$ against $2 \mathrm{~L}$ graves are negligible, and the distribution of graves with one or the other, or both, shows no separation between the two forms (Figure 7). We find the argument based on these pot forms for two enduring affiliative social groups unconvincing.

Both Bayard and Bacus identified the presence of a mound over a grave as a significant index of differential social status. Bacus concluded that during the early Bronze Age, "females receive greater post interment ritual and memorializing practices as represented by the mounds" (Bacus 2006: 112). In what would be a first for Southeast Asian mortuary data, she noted the presence of "gendered hierarchical practices". No other prehistoric site in Southeast Asia has identified a distinction between men and women. Both were treated equally in mortuary rituals right up to the end of the Iron Age. The distribution of Bronze Age burials at Non Nok Tha 1968 shows that men and women were interred alongside each other on the same rows (Figure 8). The majority of burial mounds were recorded during the 1966 season of excavations. As mentioned earlier, many difficulties were encountered that year: an inexperienced work force, poor tools, rapidly drying cultural layers when exposed to the sun and very hard deposits that could not be screened. Apart from Non Nok Tha, no mound over a prehistoric grave has, to our knowledge, ever been encountered in Southeast Asia. To have identified so many in a site with a cultural stratigraphy a little over a metre deep is an astonishing achievement, and there must be an element of doubt over their authenticity. However, on the assumption that they are indeed valid, the details for all graves with mounds are set out in Table 5 .

The actual figures for the Bronze Age are six females interred with the alleged mounds, and three men. This is not considered a large enough sample to assert that women were given the greater post interment ritual. The mortuary offerings with the women are as follows. Burial 8 was accompanied by a bone tool, three whetstones and a block of sandstone. Three of the 14 non-ceramic offerings are given by Bayard as "human remains". In a cemetery site riddled with intercutting graves, it is suggested that extraneous human bones should not be counted as mortuary offerings. Thus burial 81 of EP3 cut through burial 78, removing the skull which is found at the foot of the later skeleton (Bayard 2010: 415). Bayard also lists 21 pottery vessels with this individual, but only 17 are given a form number. Burial 2 contained a bone tool, bovid and pig bones, two whetstones and a block of sandstone, in addition to five pots. Burial 28 had four pots, a bronze casting mould, a pig's bone and two whetstones. Burial 59 was accompanied by a pig bone and four pots. In the case of burial 103 , there were some shell disc beads at the waist, 


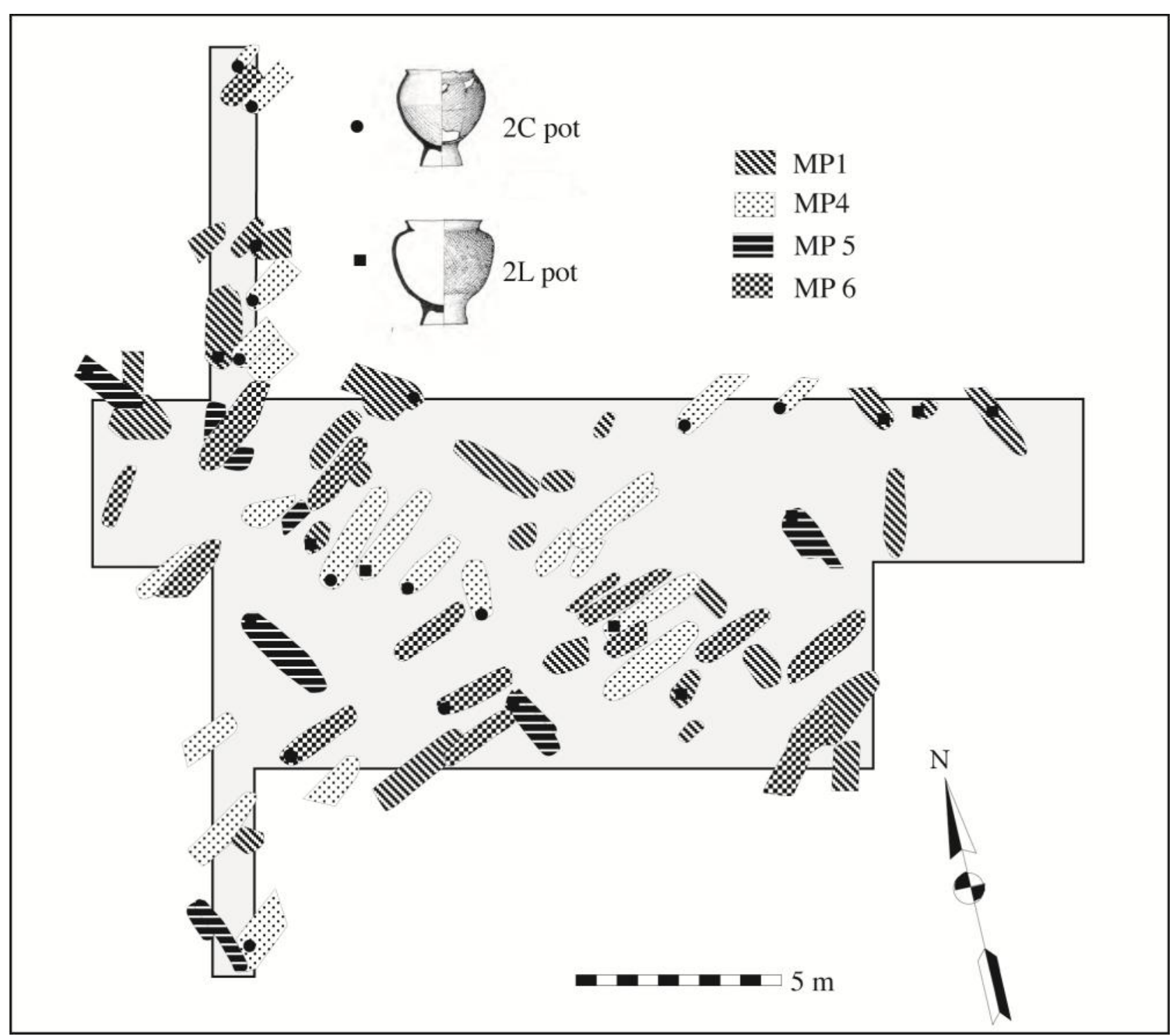

Figure 7: The distribution of 2C and 2L pot forms in the Bronze Age cemetery of Non Nok Tha, 1968 season

a whetstone, four blocks of sandstone and the bones of a bovid, pig and a dog in addition to 12 pots. Finally, burial 30 also had cattle and pig bones, a grinding stone and five pots.

The three males with alleged mounds were accompanied, in the case of burial 32, by two casting moulds and two pots. Burial 108 had some red ochre, a block of sandstone, a bovid bone and a pot. Burial 77 had nine pots in addition to three cattle bones, two pig bones and a grinding stone.

At issue is whether those interred under mounds were wealthier than those without. There are several in the latter category that were accompanied by as many, if not more, mortuary offerings than those with mounds. Thus burial 71 of MP1 was found with 17 pots and cow bones, while burial 55, a male, was 15 pots and a whetstone. Burial 103, a female, had 12 pots, shell beads, cattle and pig bones, red ochre, a bivalve shell and a whetstone. The extreme rarity of exotic grave goods at Non Nok Tha highlights the significance of bronze, since the copper and tin had to come from some distance. Bronze axes are found in burial 70 of the 1966 season, and burials 1, 85 and 90 of the 1968 season. Five bronze bracelets were found with burial 63, 17 with burial 90 (both 1966), four with burial 15 and one with burial 23 (both 1968). None of these was found under a mound. It is concluded that the putative mounds were not a significant factor in identifying social ranking or gender distinctions at Non Nok Tha.

The social interpretations of Bayard, MacDonald and Bacus have in common a duration for the Bronze Age well exceeding a millennium. The new chronology, however, indicates that the Bronze Age cemetery lasted for three to four centuries at most. It is suggested that the 


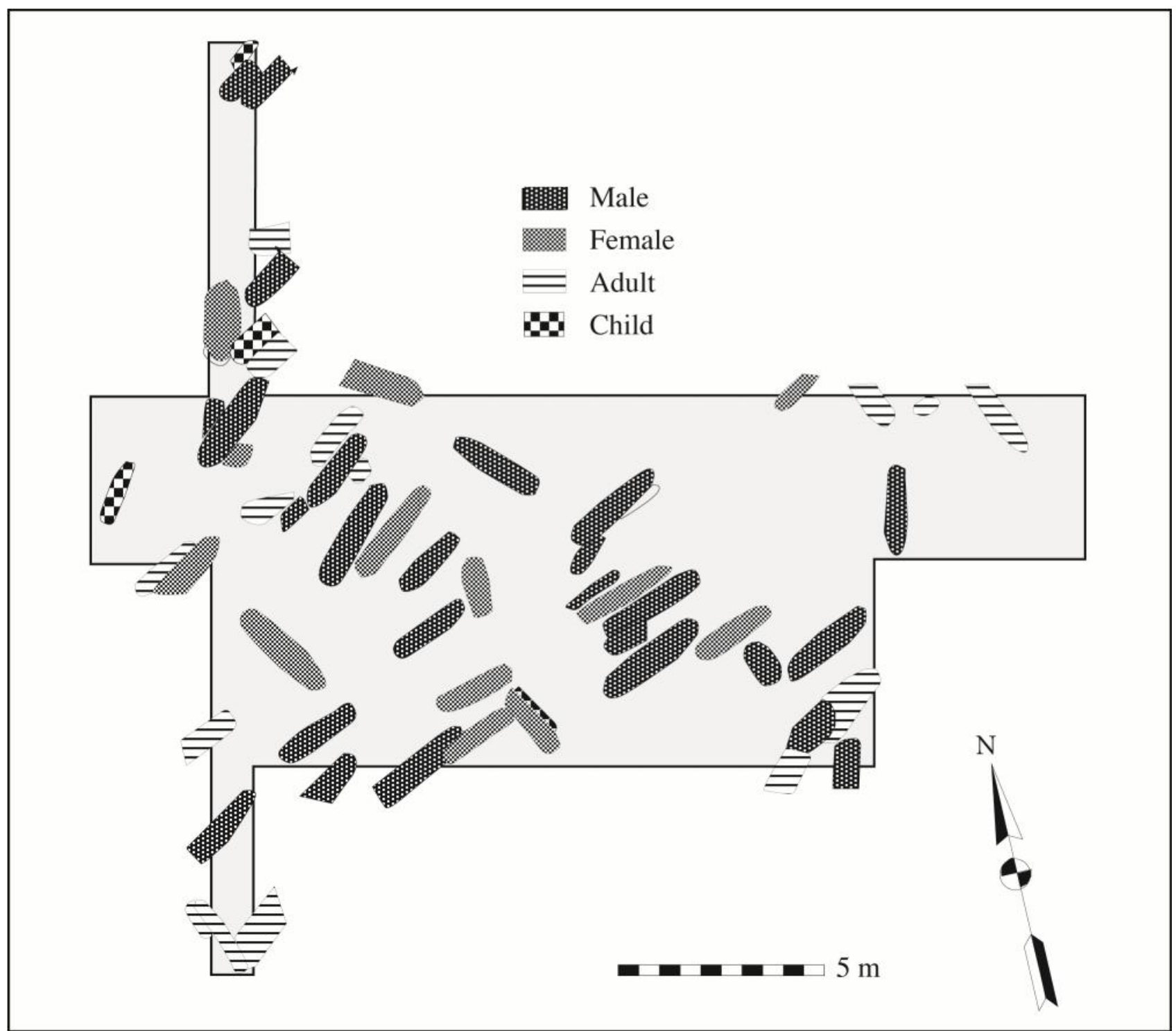

Figure 8: The distribution of middle period male, female, adult and child burials at Non Nok Tha, 1968 season

layout of the burials supports this interpretation. Figure 9 shows the plan of the Bronze Age graves from the four phases represented in the 1968 excavation. When combined, graves of the different phases commonly slot together into a coherent overall set of rows. Indeed, the integration of the graves from MP4 and 6 is particularly clear. We suggest that the chance of such a pattern occurring over a period of 50 human generations is vanishingly small. Moreover, since the excavations at Non Nok Tha, several more Bronze Age cemetery plans have been identified and in all cases, we find that burials were laid out in rows over a relatively short period, and never approaching a millennium or more.

\section{CONCLUSIONS}

Movius (1960), speaking of the European Upper Palaeolithic, once famously stressed that "Time alone is the lens that can throw it into focus". For almost half a century, the status and place of Non Nok Tha in the prehistory of Southeast Asia has fluctuated within each successive attempt to bolt down its chronology. Writing in 1972, Solheim claimed that the socketed axe from burial 90 dated "from about $3500 \mathrm{BC}$ - the oldest known metal tool coming from Southeast Asia, and the oldest socketed tool yet found anywhere" (Solheim 1972: 36). Eight years later, Bayard sustained this interpretation when he wrote that "I believe that the recent Ban Chiang evidence makes it highly likely that bronze metallurgy was well developed before 3000 BC" (Bayard 1980: 105). MacDonald set the beginning of the Bronze Age at Non Nok Tha in about 1500 BC, while Bacus preferred a date of $2000 \mathrm{BC}$. White and Hamilton (2009) cite Non Nok Tha as providing supporting evidence for the beginning of the Bronze Age at Ban Chiang in the vicinity of $2000 \mathrm{BC}$, noting that "there is evidence that the oldest metal there, including a remarkable, thin-walled, deep-socketed tin-bronze im- 

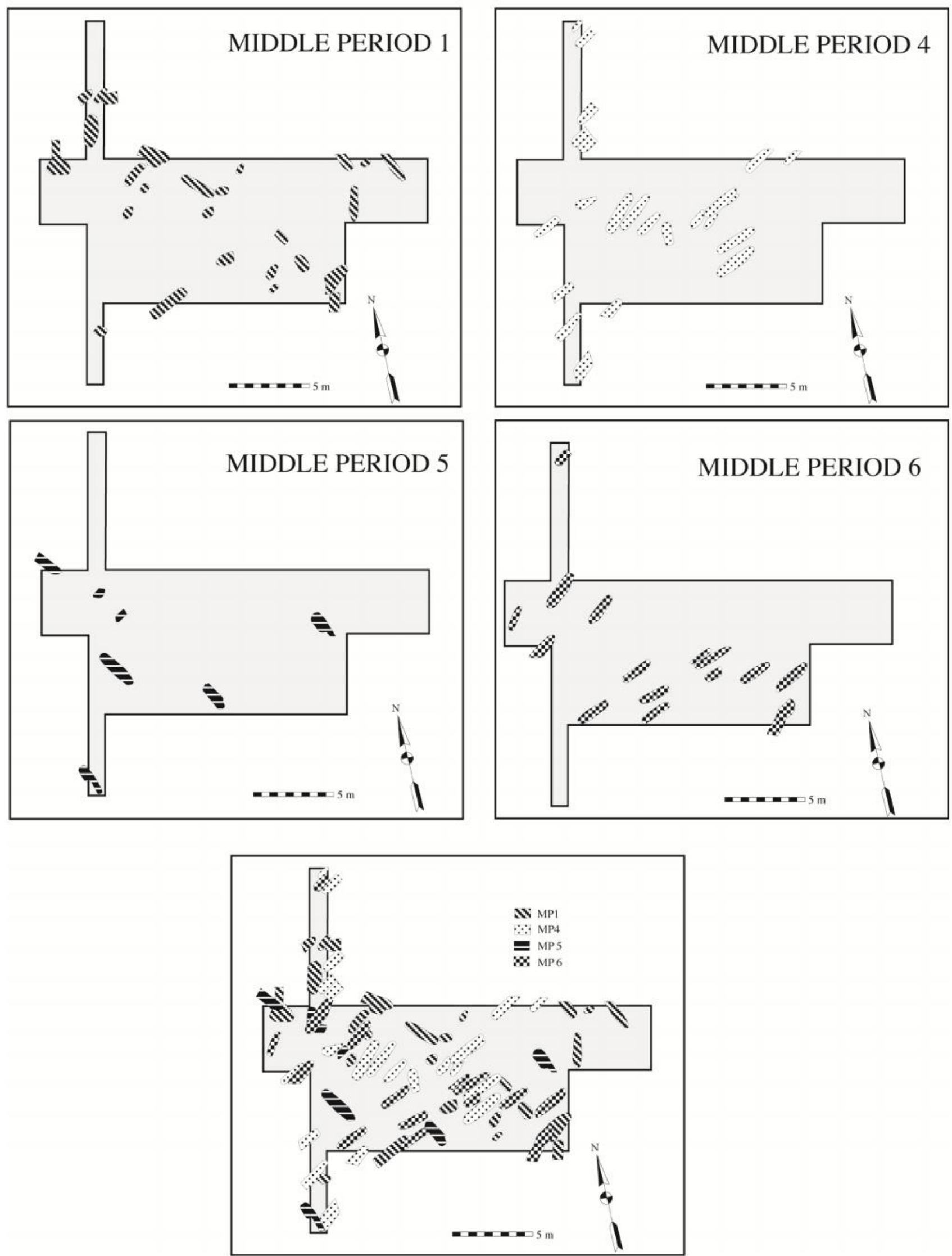

Figure 9: The distribution of graves in the Middle Period at Non Nok Tha during the 1968 season 
plement ..... could date to the late third millennium BC" (White and Hamilton 2009: 363).

Sufficient collagen was present in 14 of the sampled Non Nok Tha human skeletons to obtain AMS radiocarbon determinations following ultrafiltration protocols. They span the first settlement during EP1 to the late Bronze Age MP6. Initial settlement is placed in the $14^{\text {th }}$ century BC, with the Neolithic EP2 ending in the mid- $11^{\text {th }}$ century. The early Bronze Age falls in the $10^{\text {th }}$ century $\mathrm{BC}$, while MP3-6 cover two or three centuries, ending in about 600 B.C. These determinations closely match those recently obtained for Ban Non Wat, Ban Chiang and Ban Lum Khao. All four indicate settlement of the Khorat Plateau by Neolithic rice farmers in the mid-second millennium $\mathrm{BC}$, and a virtually simultaneous transition into the Bronze Age in the mid to late $11^{\text {th }}$ century BC.

The new Non Nok Tha chronology adds weight to the hypothesis that the stimuli for the Southeast Asian Bronze Age were generated through the exchange of knowledge, very probably involving movement of skilled founders, with the expanding Bronze traditions of the late Shang and early Zhou dynasties (Ciarla 2007, Pigott and Ciarla 2007, Higham et al. 2011). It adds a further reason to set aside White and Hamilton's (2009) model for a much earlier stimulus generated from the Seima-Turbino metal working complex of the Urals, that by-passed the Central Plains and Yangtze late Neolithic societies, to reach the site of Ban Chiang by 2000-1800 BC.

Identifying an unprecedented and unsuspected ritual complexity and wealth in the early Bronze Age at Ban Non Wat is a foil to reviewing earlier interpretations of the social status of the occupants at Non Nok Tha. Despite the several attempts to seek evidence for ranked divisions there, the mortuary offerings were at all times modest, dominated by locally manufactured ceramic vessels, along with pig and cattle bones, whetstones and bivalve shells. Prestige items with an exotic origin are very rare. The duration of the Bronze Age at Non Nok Tha has been compressed into three or four centuries, rather than over two millennia. It is concluded that this site was the cemetery of a Neolithic to Bronze Age community of farmers who lived in a region of the Khorat Plateau remote from the major exchange routes that brought social leverage to those more strategically located.

\section{ACKNOWLEDGEMENTS}

I (Charles Higham) became involved in working on the faunal remains from Non Nok Tha in 1968 (Higham 1975). I remain grateful to Donn Bayard for this invitation. For the ensuing 32 years of Bayard's life, we exchanged contrasting views on the status of Non Nok Tha. Whenever our paths crossed, I did the same with Bill Solheim always in the most cordial and collegial atmosphere. We dedicate this paper to their memory and contribution to Southeast Asian prehistory in the sure knowledge that they would appreciate what will, we hope, prove to be a defining benchmark in resolving the chronology and status of this iconic site.
The radiocarbon determinations on human bone were funded by a grant from the Marsden Fund of New Zealand. We are most grateful to Dr Vadhana Subhavan of the Sood Sangvichien Prehistoric Museum \& Laboratory of the Department of Anatomy, Siriraj Hospital Bangkok, for allowing us to sample the bones from the 1966 season at Non Nok Tha. Professor Debra L. Martin of the Department of Anthropology, University of Nevada, kindly arranged to sample the human bones from the 1968 season. We acknowledge with gratitude the careful analytical work of staff at the Oxford Radiocarbon Accelerator Unit at the University of Oxford, UK.

\section{REFERENCES}

Bacus, Elizabeth, 2006. Social identities in Bronze Age Northeast Thailand: intersections of gender, status and ranking at Non Nok Tha. In E.A. Bacus, I.C. Glover and V.C. Pigott (eds.) Uncovering Southeast Asia's Past, pp. 105115. Singapore, NUS Press.

Bayard, Donn. 1971. Non Nok Tha. The 1968 Excavations: Procedure, Stratigraphy and a Summary of the Evidence. Dunedin, Otago University Monographs in Prehistoric Anthropology No. 4.

Bayard, Donn. 1980. The roots of Indochinese civilization: recent developments in the prehistory of Southeast Asia. Pacific Affairs 53: 89-114.

Bayard, Donn. 2010a. The chronology. In D.T. Bayard and W.G. Solheim II (eds.) Archaeological Excavations at Non Nok Tha, Northeastern Thailand 1965-1968, pp. 121163. University of Guam, Micronesian Area Research Center.

Bayard, Donn. 2010b. The burials and their implications. In D.T. Bayard and W.G. Solheim II (eds.) Archaeological Excavations at Non Nok Tha, Northeastern Thailand 1965-1968, pp. 403-465. University of Guam, Micronesian Area Research Center.

Bayliss, Alex, Christopher Bronk Ramsey, Johannes van der Plicht and Alasdair Whittle. 2007. Bradshaw and Bayes: towards a timetable for the Neolithic. Cambridge Archaeological Journal 17 (Supplement): 1-28.

Berstan, Robert, Andrew Stott, Steven Minnit, Christopher Bronk Ramsey, Robert Hedges, and Richard Evershed. 2008. Direct dating of pottery from its organic residues: new precision using compound-specific carbon isotopes. Antiquity 82: 702-713.

Bonsall, Clive, Gordon Cook, Joni Manson and David Sanderson. 2002. Direct dating of Neolithic pottery: progress and prospects. Documenta Praehistorica 29: 47-59.

Brock, Fiona, Thomas Higham, Peter Ditchfield and Christopher Bronk Ramsey. 2010a. Current pretreatment methods for AMS radiocarbon dating at the Oxford Radiocarbon Accelerator Unit (ORAU). Radiocarbon 52: 103-112.

Brock, Fiona, Thomas Higham and Christopher Bronk Ramsey. 2010b. Pre-screening techniques for identification of samples suitable for radiocarbon dating of poorly preserved bones. Journal of Archaeological Science 37: 855865 .

Bronk Ramsey, Christopher. 2001. Development of the radiocarbon calibration program OxCal. Radiocarbon 43 (2A): 355-363. 
Brown, Tom, Erle Nelson, John Vogel, and John Southon. 1988. Improved collagen extraction by modified Longin method. Radiocarbon 30: 171-177.

Buck, Caitlin, William Cavanagh and Cliff Litton. 1996. Bayesian approach to interpreting archaeological data. Chichester: John Wiley and Sons.

Ciarla, Roberto. 2007. Rethinking Yuanglongpo. The case for technological links between Lingnan (PRC) and Central Thailand during the Bronze Age. East and West 57: 305328.

Higham, Charles. 1975. Non Nok Tha: The Faunal Remains. Dunedin: University of Otago Monographs in Prehistoric Anthropology 7.

Higham, Charles. 2011. The Bronze Age of Southeast Asia: new insight on social change from Ban Non Wat. Cambridge Archaeological Journal 21: 365-89.

Higham, Charles and Higham, Thomas. 2009. A new chronological framework for prehistoric Southeast Asia, based on a Bayesian model from Ban Non Wat. Antiquity 83: 125-44.

Higham, Charles, Thomas Higham, Katerina Douka, Roberto Ciarla, Amphan Kijngam and Fiorella Rispoli. 2011. The origins of the Bronze Age of Southeast Asia. Journal of World Prehistory 24: 227-274.

Higham, Charles, Thomas Higham and Katerina Douka. 2015 (in submission). A new chronological framework for the Bronze Age of Southeast Asia.

Higham, Charles and Amphan Kijngam (eds.). 1984. Prehistoric Excavations in Northeast Thailand: Excavations at Ban Na Di, Ban Chiang Hian, Ban Muang Phruk, Ban Sangui, Non Noi and Ban Kho Noi. Oxford: British Archaeological Reports, International Series 231(i-iii).

Higham, Charles and Amphan Kijngam (eds.). 2012. The Origins of the Civilization of Angkor. Volume V. The Excavation Ban Non Wat: the Bronze Age. Bangkok: The Fine Arts Department of Thailand.

Higham, Charles and Rachanie Thosarat (eds.). 2005. The Origins of the Civilization of Angkor. Volume 1. The Excavation of Ban Lum Khao. Bangkok, The Fine Arts Department of Thailand.

Higham, Thomas, Roger Jacobi and Christopher Bronk Ramsey. 2006. AMS radiocarbon dating of ancient bone using ultrafiltration. Radiocarbon 48: 179-195.

Macdonald, William. 1980. Some Implications of Societal Complexity: Organisational Variability at Non Nok Tha, Thailand (2000-0 B.C.). Ph.D. thesis, University of Michigan, Ann Arbor.

Movius, Hallam. 1960. Radiocarbon dates and Upper Palaeolithic archaeology in Central and Western Europe. Current Anthropology 1: 355-391.

Pigott, Vincent and Roberto Ciarla. 2007. On the origins of metallurgy in prehistoric Southeast Asia. In S. La Niece, D. Hook and P. Craddock (eds.) Metals and Mines, pp. 76-88. London: Archetype Publications in association with the British Museum.

Parker, Hamilton. 2010. Excavations at Non Nok Tha: 1965 1966. In D.T. Bayard and W.G. Solheim II (eds.) Archaeological Excavations at Non Nok Tha, Northeastern Thailand 1965-1968, pp. 59-97. University of Guam, Micronesian Area Research Center.
Peebles, Christopher and Kus, Susan. 1977. Some archaeological correlates of ranked societies. American Antiquity 42: 421-448.

Reimer, Paula, Mike Baillie, Edouard Bard, Alex Bayliss, Warren Beck et al. 2004. Intcal04 terrestrial radiocarbon age calibration, 0-26 cal kyr BP. Radiocarbon 46: 1029-1058.

Solheim, Wilhelm. 1972. An earlier agricultural revolution. Scientific American CCVI: 34-41.

Spriggs, Matthew. 1996-7. The dating of Non Nok Tha and the 'Gakashuin factor'. In D. Bulbeck and N. Barnard (eds.) Ancient Chinese and Southeast Asian Bronze Cultures, pp. 941-948. SMC Publishing, Taipei.

Stuiver, Minze and Henry Polach. 1977. Reporting of ${ }^{14} \mathrm{C}$ data. Radiocarbon 19: 355-363.

White Joyce and Hamilton Elizabeth. 2009. The transmission of early Bronze Age technology to Thailand: new perspectives. Journal of World Prehistory 22: 357-397. 